DOI: $10.24326 /$ fmpmsa.2017.20

\title{
DETERMINATION OF THE COEFFICIENT OF INITIAL DRYING SPEED OF SELECTED VEGETABLES
}

\author{
Ewa GOLISZ, Jędrzej TRAJER, Patrycja SOKOLOWSKA, Małgorzata JAROS \\ Faculty of Production Engineering, Warsaw University Life of Sciences-SGGW, POLAND \\ E-mail of corresponding author: ewa_golisz@sggw.pl
}

Keywords: convective drying, carrot, beet, parsley, celery, sustainable agriculture

\begin{abstract}
Efficient production of safe, high quality food is an important element of sustainable agriculture. Fruits and vegetables belong to an exceptional group of materials in food processing, and one method of preservation of growing production of fruits and vegetables is drying them. The work analyses the dependence of the initial drying speed coefficient in the first stage of drying on the initial moisture content in the process of convective drying, using cruciferous (root vegetables), namely, carrot, parsley, celery and beet. Samples of three different thicknesses $(3,5$ and $7 \mathrm{~mm})$ were dried at three different temperatures $\left(50,60\right.$ and $\left.70^{\circ} \mathrm{C}\right)$, with the constant flow speed of the drying agent. The results were presented graphically, in the form of charts. As expected, the analysis of the results showed that the drying process is faster for materials with higher initial water content. The coefficient of initial drying speed reached lower values for thicker slices, and increased together with the temperature of the drying agent.
\end{abstract}

\section{INTRODUCTION}

Fruits and vegetables are an exceptional group of materials in food processing as nutrients they contain are indispensable for appropriate functioning of human organisms. Efficient production of safe, high quality food is an important element of sustainable agriculture. Food products with long expiry date in the form of concentrates, including dried fruits and vegetables are becoming increasingly common. Thermal processes belong to one of the most important and popular methods of food preservation, as they ensure microbiological stability, enzyme inactivation, and decrease water activity by decreasing its content or availability. Drying is one of the oldest methods used by human for food preservation (Lewicki, 2006). It involves water removal from products in order to decrease its chemical activity (Janowicz 2012). During drying, the material changes its physical properties, including drying shrinkage, which manifests in the reduction of the volume of the material being dried (Wang and Brennan, 1995)

There are numerous methods of drying, with the most popular one, used on industrial scale, being convective drying, which is also one of the most destructive methods of food preservation (Alibas, 2007, Stępień 2009).

One of the main notions that define the process of drying is drying kinetics, i.e. changes of temperature and water content in the material during drying (Strumiłło, 1983). Knowledge of drying kinetics is indispensable for optimization and management of the process of drying on the production scale. Numerous authors have conducted research on drying kinetics, e.g. Jaros 1999a (red beet, carrot), Górnicki 2000 (parsley), Zaremba 2004 (celery), Łapczyńska-Kordon and Krzysztofik 2006 (red beet), Jałoszyński and Szarycz 2011 (carrot).

Drying may be divided into two stages. In the first stage the drying speed is constant, and in the second, it decreases (Pabis, 1982, Kneule 1970). The drying speed in the first stage depends on water content in the material being dried and the temperature of the drying 
gas. As experiments and observations show, the drying speed also depends on the size of particles being dried (Jaros, 1999b).

According to Jaros (1999b), changes in water content in this period may be approximated by the polynomial of the third order:

$$
u(\tau)=u_{0}-k_{0} \tau+\frac{s k_{0}{ }^{2}}{3 u_{0}} \tau^{2}-\frac{s^{2} k_{0}{ }^{3}}{27 u_{0}{ }^{2}} \tau^{3}
$$

where:

$$
\begin{aligned}
& \mathrm{u} \text { - moisture content, } \mathrm{kg} / \mathrm{kg} \\
& \tau \text { - drying time, min } \\
& \mathrm{s} \text { - drying shrinkage coefficient }
\end{aligned}
$$

Parameter $\mathrm{k}_{0}$ in the equation ought to be interpreted as the coefficient of constant drying speed at the beginning of the process (Jaros, 1999a). In the first period, drying speed also depends on the area of mass exchange and on the difference between the temperature of the material surface and the temperature of the drying agent. In consequence, different values of drying speed coefficient may be obtained for the same raw material with different degree of fragmentation. It results from the dependence that the area of the material with the same volume increases together with the degree of fragmentation (Jaros, 1999b).

\section{AIM AND SCOPE OF WORK}

The goal of work was to determine the value of the coefficient of the initial drying speed for selected root vegetables, i.e. carrot, parsley, celery and beet.

The scope of work included:

- drying fragmented vegetables in the form of slices of three thicknesses $(3,5$ and $7 \mathrm{~mm}$ ) in forced convection conditions (at the speed of the drying agent equal $1.0 \mathrm{~m} / \mathrm{s}$ ) in the tunnel drier in three temperatures of the drying agent $\left(50,60\right.$ and $\left.70^{\circ} \mathrm{C}\right)$

- measurements of mass changes during drying

- determination of the initial moisture content.

\section{RESULTS AND DISCUSSION}

The coefficient of the initial drying speed was determined using linear regression method (Jaros 1999a, Golisz 2003) based on the measurements of drying kinetics of selected vegetables. As the goal was to study kinetics of the first stage of drying, the vegetables were dried to the water content of $2 \mathrm{~kg} \mathrm{H}_{2} \mathrm{O} / \mathrm{kg}$ d.s. Depending on the temperature, drying time ranged from 180 to $240 \mathrm{~min}$. Water content was determined based on the changes of the mass of samples $\mathrm{M}(\tau)$ during drying, and the mass of dry substance $\mathrm{M}_{\mathrm{s}}$, and calculated from the following formula:

$$
u(\tau)=\frac{M(\tau)-M_{s}}{M_{s}}
$$

The results of the research on the dependence of the coefficient of the initial drying speed on the initial moisture content considering the type of vegetable, slice thickness and the temperature of drying are presented in the form of graphs. 
Figure 1 shows an example graph of the dependence of the coefficient of the initial drying speed on the initial water content for carrot, considering the thickness of slices and drying temperature. Initial water content of the examined slices of carrot ranged between 5.3 and $7.4 \mathrm{~kg} \mathrm{H} \mathrm{H}_{2} \mathrm{O} / \mathrm{kg}$ dry substance, and the coefficient of the initial drying speed ranged between 0.03 and $0.0721 / \mathrm{min}$. As expected, the observations confirmed that the drying process lasted longer for thicker slices, for which the coefficient $\mathrm{k}_{0}$ had lower values than for thinner slices.

For parsley, the initial water content ranged between approx. 4 and $5.3 \mathrm{~kg} \mathrm{H}_{2} \mathrm{O} / \mathrm{kg}$ dry substance, and the coefficient of the intitial drying speed reached values from approx. $0.022 \mathrm{1} / \mathrm{min}$ for $7 \mathrm{~mm}$-thick slicess dried at the temperature of $50^{\circ} \mathrm{C}$ to approx. 0.053 $1 / \mathrm{min}$ for $3 \mathrm{~mm}$-thick slices dried at the temperature of $70^{\circ} \mathrm{C}$.

The initial water content in celery ranged between 5.5 and $7.5 \mathrm{~kg} \mathrm{H}_{2} \mathrm{O} / \mathrm{kg}$ dry substance, and the coefficient of the initial drying speed ranged from $0.021 / \mathrm{min}$ for $7 \mathrm{~mm}$ thick slices dried at the temperature of $50^{\circ} \mathrm{C}$ to $0.0561 / \mathrm{min}$ for $3 \mathrm{~mm}$ thick slices dried at the temperature of $70^{\circ} \mathrm{C}$.

For beet, the initial water content ranged from 6.2 to as much as $12 \mathrm{~kg} \mathrm{H}_{2} \mathrm{O} / \mathrm{kg}$ dry substance. The values of the drying speed coefficient, similarly to other cases, increased together with the increase in the temperature, and the decrease in slice thickness, and it reached the values ranging between 0.024 and $0.0631 / \mathrm{min}$.

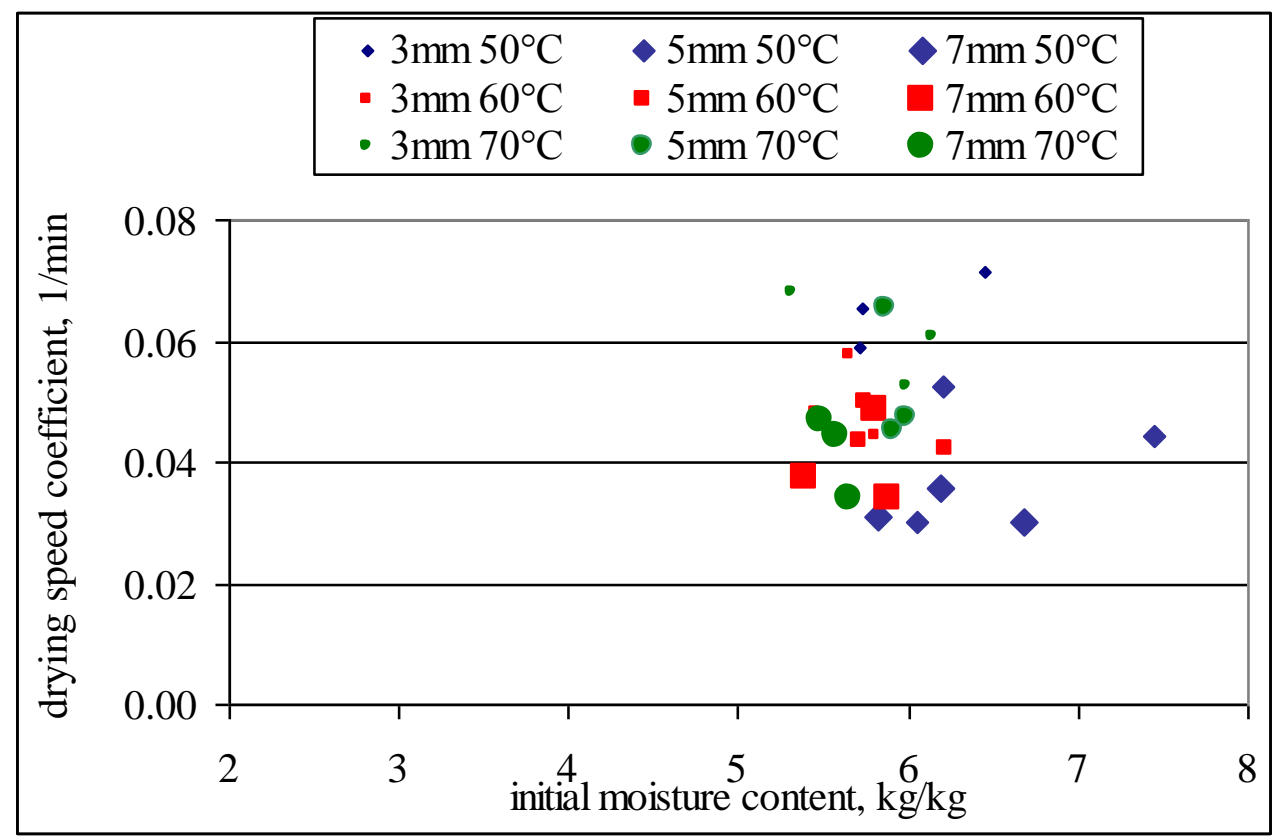

Figure 1. Dependence of the coefficient initial drying speed of carrot on the initial moisture content, considering slices thickness and drying temperature.

Next, the impact of slices thickness of the material being dried on the value of the coefficient of the initial drying speed in given drying air temperature, and the impact of the temperature on the drying speed coefficient in the first stage of drying for given slice thicknesses of the vegetables being dried was analysed. Example graphs for drying air temperature of $50^{\circ} \mathrm{C}$ and slice thickness of $3 \mathrm{~mm}$ are presented in figures 2 and 3 . 


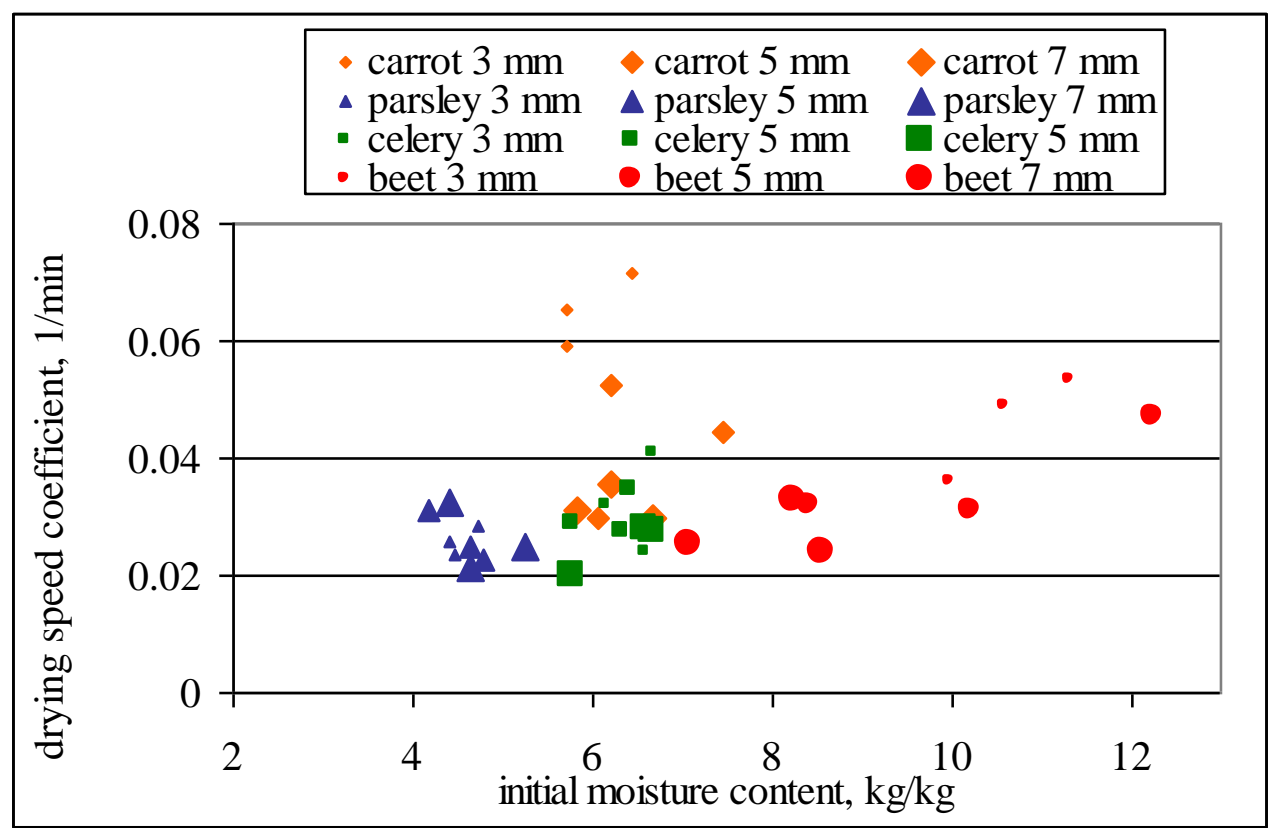

Figure 2. Dependence of the coefficient of the initial drying speed on the initial moisture content at the temperature of $50^{\circ} \mathrm{C}$, considering slices thickness

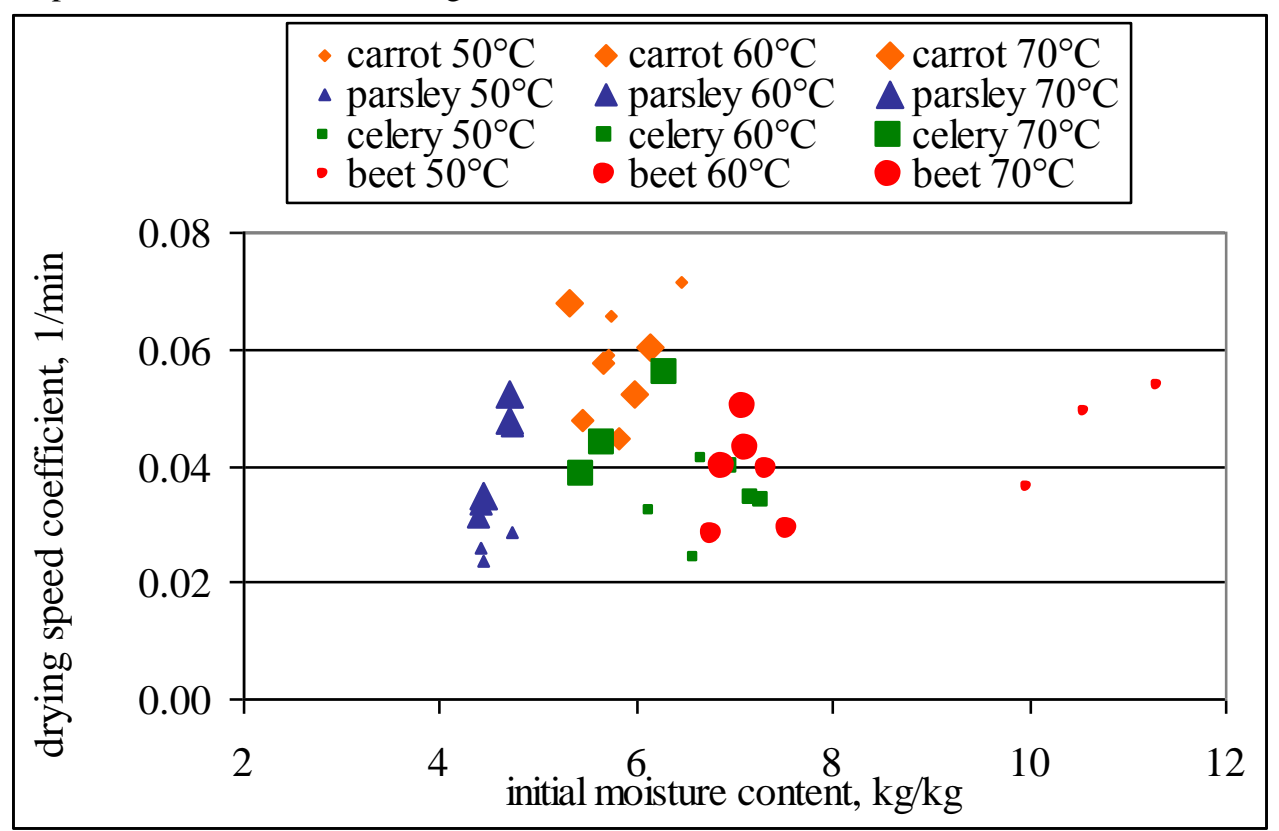

Figure 3. Dependence of the coefficient of the initial drying speed on the initial moisture content for $3 \mathrm{~mm}$ thick slices, considering drying temperature

\section{CONCLUSIONS}

The work presents the results of research on drying kinetics of root vegetables, in forced convection. Good knowledge of drying kinetics determines the possibility of optimizing and management the drying process on a production scale, which is an important element of sustainable agriculture. Four selected vegetables, i.e. carrot, parsley, celery and beet, sliced into 3, 5 and $7 \mathrm{~mm}$ thick slices, were dried in three different temperatures of drying air $\left(50,60,70^{\circ} \mathrm{C}\right)$. The coefficient of the initial drying speed reached lower values for 
thicker slices, and increased together with the increase in the drying agent temperature. The values of coefficient $\mathrm{k}_{0}$ were higher for higher initial water content in the material. It means that the drying process is faster for moister materials.

The drying process took the shortest for samples of carrot, followed by red beet, celery and parsley, which took the longest. Initial water contents for the vegetables were different, and they ranged from 4.2 to $12.2 \mathrm{~kg} / \mathrm{kg}$, which caused difficulties in results analysis. Also, within the same vegetable, the initial water content varied, which may be attributed to a large degree of inhomogeneity of the material.

Initial drying speed coefficient $\mathrm{k}_{0}$ for the examined vegetables ranged from 0.030 to 0.072 $1 / \mathrm{min}$ for carrot, $0.022-0.053 \mathrm{1} / \mathrm{min}$ for parsley, $0.020-0.0561 / \mathrm{min}$ for celery, $0.024-$ $0.0641 / \mathrm{min}$ for beet. Initial drying speed coefficient $\mathrm{k}_{0}$, depending on the drying temperature reached the following values: $0.020-0.0721 / \mathrm{min}$ for the temperature of $50^{\circ} \mathrm{C}, 0.022-0.0581 / \mathrm{min}$ for temperature of $60^{\circ} \mathrm{C}$, and $0.028-0.0681 / \mathrm{min}$ for temperature of $70^{\circ} \mathrm{C}$.

Depending on slice thickness, initial drying speed coefficient $\mathrm{k}_{0}$ ranged between 0.024 and $0.072 \mathrm{1} / \mathrm{min}$ for $3 \mathrm{~mm}$ thick slices, $0.023-0.0661 / \mathrm{min}$ for $5 \mathrm{~mm}$ slices, and $0.020-$ $0.0641 / \mathrm{min}$ for $7 \mathrm{~mm}$ thick slices. It is impossible to conclusively state whether the temperature or slice thickness has greater impact on the drying speed.

\section{REFERENCES}

Alibas, I. (2007). Energy consumption and colour characteristic of nettle leaves during microwave, vacuum and convective drying. Biosystems Engineering 96(4), pp.495-502

Golisz, E. (2003). Modelowanie współczynnika szybkości suszenia pora. Inżynieria Rolnicza 13(55)

Górnicki, K. (2000). Modelowanie procesu konwekcyjnego suszenia korzeni pietruszki. Praca doktorska, SGGW

Jałoszyński, K., Lech, K., Szarycz, M. (2011). Zależność współczynnika dyfuzji wody w kostkach marchwi od temperatury powietrza suszącego. Inżynieria Rolnicza 5(130)

Janowicz, M. (2012). Wpływ wysokociśnieniowej obróbki wstępnej na suszenie konwekcyjne jabłek, Wydawnictwo SGGW

Jaros, M. (1999a). Analiza i wyznaczanie wartości współczynnika szybkości suszenia w procesie konwekcyjnego suszenia warzyw, [w] Konwekcyjne suszenie warzyw. Teoria i praktyka (praca zbiorowa pod red. Pabis S.), Polskie Towarzystwo Inżynierii Rolniczej

Jaros, M. (1999b). Kinetyka suszenia warzyw. Rozprawy Naukowe Akademii Rolniczej w Lublinie (224), Wydawnictwo Akademii Rolniczej w Lublinie

Kneule, F. (1970). Suszenie, Arkady

Łapczyńska-Kordon, B., Krzysztofik, B. (2008), Wpływ metod i parametrów suszenia na zmiany barwy suszów owocowo - warzywnych. Inżynieria Rolnicza 1(99)

Lewicki, P.P. (2006). Design of hot air drying for better foods. Trends in Food Science and Technology 17(4), pp.153-163

Pabis, S. (1982). Teoria konwekcyjnego suszenia produktów rolniczych, Państwowe Wydawnictwo Rolnicze i Leśne

Stępień, B. (2009). Wpływ metody suszenia wybrane cechy mechaniczne marchwi po ponownym uwodnieniu. Inżynieria Rolnica 114 (5), pp. 267-274

Strumiłło, C. (1983). Podstawy teorii i techniki suszenia, WNT

Wang, N., Brennan, J.G. (1995) Changes in structure, density and porosity of potato during dehydration. Journal of Food Engineering 24(1), pp. 61-76

Zaremba, R. (2004). Analiza procesu konwekcyjnego suszenia krajanki selera metodą fluidyzacji. Praca doktorska, SGGW 